\title{
Seasonal trend in suspended-sediment transport from an Arctic glacier, and implications for drainage-system structure
}

\author{
RICHARD HODGKINS \\ Department of Geography, University of Cambridge, Downing Place, Cambridge CB2 3EN, England
}

\begin{abstract}
Suspended-sediment concentration (SSC) and discharge time series have been obtained for a proglacial stream draining from Scott Turnerbreen, a nontemperate glacier at $78^{\circ} \mathrm{N}$ in the Svalbard archipelago. These time series exhibit seasonal trends in diurnal hysteresis between SSC and discharge, which changes progressively from clockwise (SSC lead) to anticlockwise (SSC lag), and in the availability of sediment for fluvial transport, which increases during the season. These results contrast with those for streams draining temperate glaciers, in which a seasonal trend in diurnal hysteresis is typically not observed, and sediment supply is usually exhausted during the melt season. This contrast indicates differences in the processes of sediment acquisition and in temporal patterns of sediment transport between temperate and non-temperate glaciers, which reflect different drainage-system structures. The principal mechanism of suspended-sediment acquisition by meltwater is subaerial sediment supply to ice-marginal channels at non-temperate glaciers, whereas at temperate glaciers it is subglacial supply to basal channels. The hysteresis trend probably arises from a delaying effect, because of sediment circulation in pools and slack water adjoining the ice-marginal channels, which varies with discharge. Continuing subaerial sediment supply from heavily debris-covered ice-cored moraines during the melt season precludes sediment-supply exhaustion at Arctic glaciers but means that measurements of sediment flux give a misleading indication of the contemporary rate of glacial erosion.
\end{abstract}

\section{INTRODUCTION}

Following entrainment, suspended-sediment transport requires little energy and is limited only by sediment supply, which is invariably exceeded by stream transport capacity. Thus, the suspended load of a stream tends to reflect catchment processes, rather than channel hydraulic conditions. The suspended-sediment characteristics of proglacial streams should therefore be able to impart information about glacier drainage systems.

Repp (1988) and Bogen (1991) have discussed suspended-sediment transport in the Bayelva catchment, northwest Svalbard, in which the dominant source of sediment is the $11.7 \mathrm{~km}^{2}$ Austre Broggerbreen glacier. Repp (1988) reported annual suspended-sediment fluxes of up to $16588 \mathrm{t}$, and suggested that this indicated "a well developed and integrated network of subglacial streams and channels". A distinction was drawn between the relatively uniform seasonal suspended-sediment transport regime in the Svalbard catchment, and early-season sediment flushes observed in proglacial streams on mainland Norway (e.g. Liestol, 1967). Bogen (1991) reiterated this distinction, though suggesting that a seasonal increase in suspended-sediment transport, attributed to "a stable subglacial channel system that expands throughout the summer", was more typical in the Svalbard catchment.
Gurnell and others (1994) examined differences between proglacial suspended-sediment transport from an Arctic and an Alpine glacier, through changes in the parameters of linear regression models estimated for successive periods during melt seasons. They found that the steepest, strongest relationships between suspendedsediment concentration (SSC) and discharge occurred early in the season in the Alpine catchment (Haut Glacier d'Arolla, Switzerland), after which given discharges yielded lower values of SSC, indicating relative exhaustion of the sediment supply. However, corresponding relationships for the Arctic catchment (Austre Broggerbreen, Svalbard) steepened during the season, suggesting increasing availability of sediment for fluvial transport. Furthermore, short or negligible lags/leads between SSC and discharge time series in the Alpine catchment contrasted with a seasonal decrease in the lead of SSC over discharge, from $6 \mathrm{~h}$ to $1 \mathrm{~h}$, in the Arctic catchment. It was suggested that this decrease reflected an up-glacier migration of the dominant sediment sources with the expanding area of meltwater generation, and probably also the effects of "variable ground thaw processes" in permafrost (Gurnell and others, 1994).

The purposes of this paper are to discuss seasonal variation in suspended-sediment transport at a nontemperate ("cold-based") glacier in the Arctic, to make 
inferences about its drainage-system structure and to contrast these with results from temperate glaciers. A distinction is made between glaciers which are wholly, or nearly wholly, below the pressure-melting temperature ("non-temperate", e.g. Austre Broggerbreen), and those which are wholly, or nearly wholly, at the pressuremelting temperature ("temperate", e.g. Haut Glacier d'Arolla). It might intuitively be expected that contrasting patterns of sediment acquisition and transport should arise between glaciers at which the main meltwater flowpaths are either subglacial (in the temperate case) or subaerial (a possibility in the non-temperate case); this idea is addressed in this paper.

\section{DATA GOLLECTION}

The data presented in this paper were obtained from the proglacial stream of Scott Turnerbreen, a $3.3 \mathrm{~km}^{2}$ glacier occupying a $12.8 \mathrm{~km}^{2}$ catchment of central Svalbard $\left(78^{\circ} 06^{\prime} \mathrm{N}, 15^{\circ} 57^{\prime} \mathrm{E}\right)$. The maximum thickness of the glacier is $75 \mathrm{~m}$, and temperature measurements in boreholes indicate that the ice is below the pressure-melting temperature throughout (Hodgkins, 1994). Meltwater drainage from the glacier is dominated by two icemarginal channels, which largely flow sub-aerially and hence at atmospheric pressure; these coalesce about $150 \mathrm{~m}$ in front of the glacier to form the main proglacial stream.

A record of SSC was obtained by discrete sampling in a stable reach of the main proglacial stream $250 \mathrm{~m}$ downstream of the confluence. Measurements span $26 \mathrm{~d}$ from 20 July to 15 August 1992. As the mean diurnal maximum air temperature in the catchment typically exceeds $0^{\circ} \mathrm{C}$ only in June, July and August, this period is considered to be representative of the main part of the short melt season. Early-season suspended-sediment flushes have not been observed at this glacier (Hodgkins, 1994). Water samples were obtained automatically with an Epic Products 1011 sampler. As the stream was highly turbulent, point sampling should have yielded representative estimates of SSC Gurnell and others, 1992b). The sampling interval varied between 1 and $3 \mathrm{~h}$ according to the frequency with which samples could be processed. Samples were filtered in a Perspex pressurefiltration apparatus, through pre-weighed Whatman grade 40 papers, with an initial penetration pore size of $8 \mu \mathrm{m}$ (although the effective pore size is reduced during filtration (Gurnell, 1987)), and returned to the UK for drying and reweighing in order to determine SSC.

The accuracy of the SSC determinations is affected by four factors: (1) Variation in the water sample volume: the error in water volumes collected by the specified sampler is $\pm 0.5 \mathrm{ml}$, and with the volume of samples collected being $500 \mathrm{ml}$, the corresponding error in SSC is $\pm 0.05 \%$ (at all concentrations). (2) Precision of the analytical balance used to weigh the papers, which was $\pm 0.1 \mathrm{mg}$; since each paper is weighed twice, this is doubled, and corresponds to an error of $\pm 0.015 \%$ of the mean SSC. (3) Error resulting from the absorption of moisture by the chosen filter paper, which is hygroscopic. From data in Gurnell and others (1992b), the error from this source can be stated as $\pm 0.16 \%$ of the mean SSC. (4) Error due to sub- $8 \mu \mathrm{m}$ particles passing through the fast-filtration paper. The exact magnitude of this error depends upon the grain-size distribution of the sediment, but from data in Gurnell and others (1992b) it is likely that there is approximately a $1 \%$ underestimation at the mean SSC. This is therefore the most significant source of error.

Stage was recorded hourly, in the same reach as SSC, with a Sandhurst Technology LH-177 pressure transducer and Grant Instruments SQ32 data logger. The resulting time series was calibrated by means of linear regression with discrete discharge measurements obtained by the relative dilution technique (Water Research Association, 1970). The substance diluted was $5 \mathrm{~g}$ Rhodamine B fluorescent dye in 11 of stream water. The dye was detected by continuous-flow fluorometry with a Turner Designs Model 10 fluorometer. The accuracy of the stagedischarge relationship, estimated from the standard error of the estimate, is $\pm 13 \%$. The discharge record ends $2 \mathrm{~d}$ later than the $\mathrm{SSC}$ record $(28 \mathrm{~d}$ long).

\section{SEASONAL EVOLUTION OF SUSPENDED- SEDIMENT TRANSPORT}

The SSC and discharge time series obtained from the proglacial stream of Scott Turnerbreen are shown in Figure 1. Diurnal cycles occur throughout both series, and there is a near-exponential decline in discharge from around 29 July, as the end of the melt season is approached. In order to allow examination of the seasonal evolution of sediment transport in detail, the monitored season is divided arbitrarily into four successive intervals of $7 \mathrm{~d}$ (Fig. 1), and mean diurnal patterns of discharge and SSC are determined for each interval.

The arbitrary division of the time series avoids bringing any prior qualitative interpretation to the data. Rainfall has a negligible effect on the hydrographs; an evenly distributed total of only $11 \mathrm{~mm}$ fell during the measurement period. The mean diurnal variations of discharge and SSC, and the corresponding mean diurnal hysteresis loops, for each of the four intervals, are shown in Figure 2. It is immediately clear that both the level and

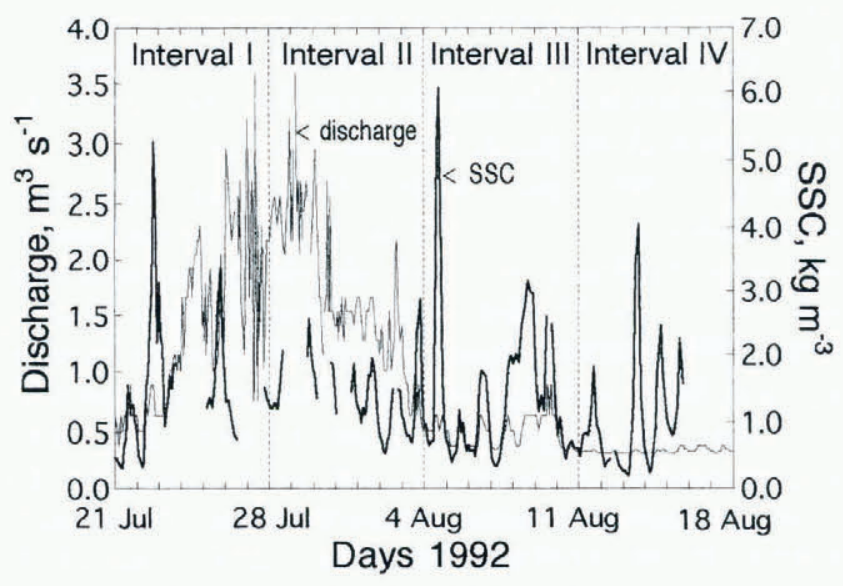

Fig. 1. Discharge and suspended-sediment concentration (SSC) time series oblained from the proglacial stream of Scott Turnerbreen, Svalbard, during the 1992 melt season, showing the division of the monitored season into four successive $7 d$ intervals. 
the range of $\mathrm{SSC}$ are more constant through the season than those of discharge, indicating that the magnitude of discharge is only a partial control on SSC.

\section{Diurnal discharge-SSC hysteresis}

There is a trend from clockwise to anticlockwise diurnal discharge-SSC hysteresis during the season (Fig. 2). Hysteresis implies a bivariate relationship in which values of the dependent variable for a given value of the independent variable differ according to whether the independent variable is increasing or decreasing. Clockwise hysteresis implies that SSC is higher on the rising limb of the diurnal hydrograph than at equivalent discharges on the falling limb, and therefore that the diurnal SSC peak leads the diurnal discharge peak. Anticlockwise hysteresis implies the reverse. Interval I exhibits the most complex hysteresis, beginning with a clockwise loop up to about $0800 \mathrm{~h}$, then failing to display a clear trend until about $1400 \mathrm{~h}$ when an anticlockwise loop is formed. Both intervals II and III show, essentially,

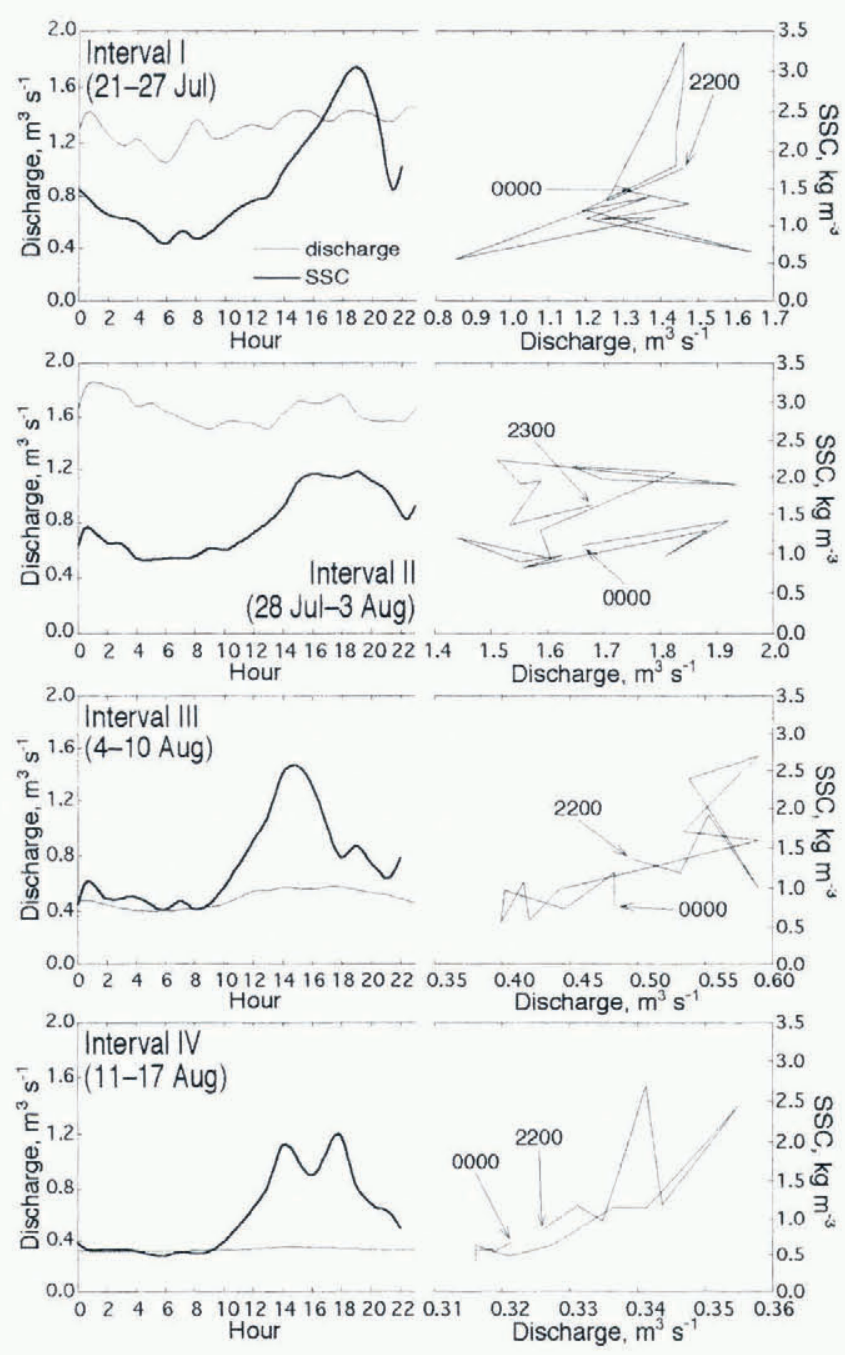

Fig. 2. Mean diurnal variation of discharge and SSC (lefihand column), and corresponding hysteresis (righthand column), for each of the four intervals indicated in Figure 1. Note that both discharge and SSC have fixed scales in the diagrams in the lefthand column, but that the discharge scale varies in those in the righthand column. first a clockwise loop and then an anticlockwise loop during the diurnal cycle, the direction change occurring between 1000 and $1200 \mathrm{~h}$ in each case, although both display some complex involutions. Interval IV exhibits the most simple hysteresis, with a generally anticlockwise single loop over the diurnal cycle. It therefore appears that a progressive shift in the overall relative timing of the diurnal discharge and SSC peaks occurs during the course of the season, such that SSC leads discharge at the start but lags it at the end.

\section{Sediment availability}

Regression models between SSC and discharge were estimated for each of the four intervals identified above, in order to determine whether there were any changes in the parameters that might indicate seasonally evolving sediment-transport mechanisms. The form of the models was deliberately kept simple, to aid interpretation. With $\log _{10} \mathrm{SSC}$ as the dependent variable and $\log _{10} Q$ (where $Q$ is discharge) as the independent variable, least-squares linear regression models, corresponding to the relationship $\mathrm{SSC}=a Q^{b}$ were estimated for each time interval. The common logarithmic transformation of each variable was identified, from a series of power transformations by a Box Cox procedure (Haworth and Vincent, 1982), as that yielding the most monotonically linear bivariate scatter which best satisfied the regression assumptions (Ferguson, 1977).

The regression models for the intervals preceding 4 August differ strongly from those following that date (Table 1). Models for intervals I and II have very low coefficients of determination that for interval $\mathrm{I}$ is not significant at the $5 \%$ level), whereas models for intervals III and IV have coefficients of determination which are an order of magnitude greater. The three statistically significant models show regression slopes which increase through the season, meaning that SSC increases by a successively greater increment, for a given increment in discharge, as the season progresses. This indicates that the availability of sediment for fluvial transport increases through the season, and that relative exhaustion of sediment supplies does not occur. However, the total quantity of sediment transported from the catchment in suspension over this period decreases, as a result of the decline in discharge (Fig. 1). Mean daily total suspendedsediment transport in the four intervals is $168 \mathrm{td}^{-1}$ in $\mathrm{I}$,

\section{Table 1. Parameters from linear regression models with $\log _{10}$ SSC as the dependent variable and $\log _{10} Q$ the independent variable. Italicised values are not significant al the $5 \%$ level. $R^{2}$ is the coefficient of determination and $n$ is the number of SSC measurements}

\begin{tabular}{lcccc}
\hline Interval (1992) & Intercept & Slope & $R^{2}$ & $n$ \\
\hline I $\quad$ (21-27 July) & 0.101 & 0.351 & 0.080 & 47 \\
II (28 July-3 Aug.) & 0.075 & 0.282 & 0.096 & 53 \\
III (4 10 Aug.) & 0.721 & 2.129 & 0.523 & 63 \\
IV (11-17 Aug.) & 4.995 & 10.38 & 0.478 & 37
\end{tabular}


$215 \mathrm{td}^{-1}$ in II, $64 \mathrm{td}^{-1}$ in III and $27 \mathrm{td}^{-1}$ in IV.

\section{IMPLICATIONS FOR THE STRUCTURE OF THE SCOTT TURNERBREEN DRAINAGE SYSTEM}

The seasonal trend in diurnal discharge-SSC hysteresis identified in this paper resembles that reported by Gurnell and others (1994). In general, clockwise diurnal hysteresis (SSC lead) may arise from the flushing out of sediment at the margins and beds of subglacial channels during rising discharges, and subsequent exhaustion of the supply (Collins, 1979; Humphrey and others, 1986). Similar behaviour is also typical of sub-aerial, openchannel flow (such as in the ice-marginal channels at Scott Turnerbreen), where it might arise by cyclic deposition and erosion in ponds in a large conduit (Humphrey and others, 1986). Fountain (1992) suggests two mechanisms which may account for anticlockwise diurnal hysteresis (SSC lag). First, a monoclinal wave, such as the rising limb of a diurnal hydrograph, propagates downstream at a velocity greater than the flow velocity of the water. Since sediment is transported at the flow velocity, rather than at the wave velocity, SSC would lag discharge. However, as this result is based on the hydraulics of pipe flow, it would not necessarily account for the observed seasonal variability in an open channel. Secondly, pools located along the course of a channel do not impede flow increases, but do allow sediment to circulate, causing its passage to be delayed (here called a "circulation-delay effect").

The explanation of the changing lead/lag of SSC at Scott Turnerbreen favoured here is therefore that, while sediment mobilisation continues to occur at rising discharge, operation of a circulation-delay effect in the ice-marginal and proglacial channels varies with discharge. At high discharges, when these channels are relatively full, the bulk of the water is transmitted rapidly through the channel, and only a small proportion is delayed in pools along the flow path, or in slack water adjoining it. At low discharges, when the channels are relatively empty, water circulating in such pools or slack water constitutes a greater proportion of the total flow, so the delay is more important. Pools and slack water effectively fill at rising discharge and subsequently empty as discharge falls, leading to temporary storage of suspended sediment on the rising limb of a diurnal hydrograph, an effect more significant at low discharges. Hence there would be an increasing trend towards anticlockwise diurnal hysteresis late in the season when discharge diminishes, which is what was observed.

The analysis presented here sustains previous evidence from Svalbard concerning the seasonal availability of sediment for fluvial transport (Repp, 1988; Bogen, 1991; Gurnell and others, 1994). However, because Scott Turnerbreen is non-temperate throughout, the suggestions of Repp (1988) and Bogen (1991) that this seasonal suspended-sediment transport pattern indicates the existence of a "well-developed" or "expanding" subglacial drainage system are not supported. Supraglacial, proglacial and ice-marginal processes provide more plausible sediment-supply mechanisms at non-temperate glaciers. Hodson's (1994) observations that suspended-sediment delivery to meltwater at Austre Broggerbreen resulted from slope failure on ice-cored moraines support the idea that surficial and marginal processes dominate sediment supply.

\section{CONTRASTS WITH TEMPERATE GLACIERS}

The seasonal trend from clockwise to anticlockwise diurnal hysteresis identified at Austre Broggerbreen and Scott Turnerbreen contrasts with results from temperate glaciers, at which discharge and SSC vary almost synchronously for much of the melt season (Gurnell and others, 1992a, 1994). This implies that, although the dominant sources of sediment probably migrate upglacier relative to the area of meltwater production at a temperate glacier, as sediment exhaustion occurs in stable down-glacier channels (Gurnell and others, 1992a), this hysteresis-generating process is less pronounced than those operating at non-temperate glaciers. Permafrost processes may be an influence on sediment availability, and hence on hysteresis, at non-temperate glaciers in the Arctic, producing a more pronounced up-glacier migration of dominant sediment sources Gurnell and others, 1994). The impact of a circulation-delay effect may also be greater in channels which are not responsive to meltwater flux, such as the ice-marginal channels at Scott Turnerbreen. The volume of these subaerial channels does not effectively change as discharge diminishes late in the melt season, because the deformation rate of the non-temperate ice at the thin glacier margins is extremely low. Opportunities for circulationdelays in re-exposed pools adjoining the channel margins therefore increase. However, since channels beneath a temperate glacier decline when discharge diminishes, as closure by ice deformation exceeds enlargement due to energy expenditure, opportunities for circulation-delays would not increase at low discharges.

The seasonal pattern of sediment availability identified at Austre Broggerbreen and Scott Turnerbreen also contrasts with that of temperate glaciers, where relative sediment-supply exhaustion is typically observed (Gurnell, 1987; Gurnell and others, 1992a, 1994). This effect is consequent upon the seasonal rationalisation of the basal drainage system, in response to the increasing meltwater flux, and the subsequent stabilisation of a small number of relatively large, efficient channels, offering access to fixed sediment supplies which are rapidly depleted. The lack of a comparable effect at a non-temperate glacier implies either that, supposing subglacial channels do exist, an unlimited amount of sediment is available to them, or that they do not become stabilised in a given location during the season. More realistically, it implies that sediment is derived from different locations altogether. The courses of the icemarginal channels at Scott Turnerbreen are through heavily debris-covered, ice-cored moraines. During the melt season, water-saturated sediment is delivered to the ice-marginal channel banks by mass-wasting. Some of the sediment enters the stream flow directly. However, most is probably mobilised during rising discharge, as the increased water volume enlarges the channels' wetted perimeters, and bank sediment becomes entrained by flowing water. Hence, a pattern of melt-driven diurnal variation is inherent in the process of sediment acquisition. 
Furthermore, the continuous supply of sediment from an abundant source by subaerial processes precludes the operation of an exhaustion effect, although the locations of the channels are stable.

\section{GLACIAL EROSION RATES}

A corollary of the sediment supply process outlined above is that caution is required in estimating the glacial erosion rate for a glacier such as Scott Turnerbreen from suspended-sediment flux data. The suspended load of the proglacial stream is not indicative of active glacial erosion, since the glacier is currently frozen to its bed, but is derived from sediment stored following glacial erosion in an earlier time period, which has provided a plentiful subaerial sediment supply as a result of sustained recent glacier retreat and thinning. This is a process similar to "paraglacial" denudation, which is said to result from the instability of glacial sediment in proglacial or postglacial fluvial environments, leading to heightened sediment transport, such that sediment yield bears little relation to the concurrent production of eroded material (Church and Ryder, 1972).

\section{CONGLUSIONS}

The suspended-sediment transport regime at Scott Turnerbreen is characterised by a seasonal trend from clockwise to anticlockwise diurnal hysteresis, and by an increasing availability of sediment for fluvial transport. These characteristics appear to be typical for nontemperate glaciers, but contrast with seasonal suspended-sediment transport regimes identified at temperate glaciers. This contrast arises from differing drainagesystem structures, predominantly subglacial at temperate glaciers but mainly ice-marginal at non-temperate glaciers. The hysteresis trend probably arises from a delaying effect, due to sediment circulation in pools and slack water adjoining ice-marginal channels, which varies with discharge. Sediment availability is determined by effectively unlimited subaerial supply to ice-marginal channels from ice-cored moraines. The suspended load of the proglacial stream of a non-temperate glacier does not therefore necessarily reflect the contemporary glacial erosion rate, since much of the sediment has been supplied subaerially, rather than subglacially.

\section{ACKNOWLEDGEMENTS}

The support of U.K. Natural Environment Research
Council studentship GT4/91/AAPS/11, and, from within the University of Cambridge, of the Gino Watkins and B. B. Roberts funds (Scott Polar Research Institute), the Department of Geography and Downing College, are gratefully acknowledged. S. Wells and M. Siegert assisted with data collection, and I. Willis and D. Collins commented helpfully on drafts of this paper.

\section{REFERENCES}

Bogen, J. 1991. Erosion and sediment transport in Svalbard. In Gjessing, Y., J. O. Hagen, K. A. Hassel, K. Sand and B. Wold, eds. Arctic hydrology: present and future tasks. Hydrology of Sualbardhydrological problems in a cold climate. Oslo, Norwegian National Committee for Hydrology, 147-158. (Report 23.)

Church, M. and J.M. Ryder. 1972. Paraglacial sedimentation: a consideration of fluvial processes conditioned by glaciation. Geol. Soc. Am. Bull., 83, 3059-3072.

Collins, D. N. 1979. Sediment concentration in melt waters as an indicator of erosion processes beneath an Alpine glacier. J. Glaciol., $2389), 247-257$.

Ferguson, R. I. 1977. Linear regression in geography. Norwich, GeoAbstracts. Concepts and Techniques in Modern Geography 15.

Fountain, A.G. 1992. Subglacial water flow inferred from stream measurements at South Cascade Glacier, Washington, U.S.A. $f$. Glaciol., 38 (128), 51-64.

Gurnell, A. M. 1987. Suspended sediment. In Gurnell, A. M. and M. J. Clark, eds. Glacio-fluvial sediment transfer: an Alpine perspective. Chichester, etc., John Wiley and Sons, 305-354.

Gurnell, A. M., M.J. Clark and C. T. Hill. 1992a. Analysis and interpretation of patterns within and between hydroclimatological time series in an Alpine glacier basin. Earth Surface Processes and Land form.s, 17 (8), 821-839.

Gurnell, A. M., M.J. Clark, C. T. Hill and J. Greenhalgh. 1992 b. Reliability and representativeness of a suspended sediment monitoring programme for a remote Alpine proglacial river. International Association of Hydrological Sciences Publication 210 (Symposium at Oslo 1992 - Erosion and Sediment Transport Monitoring Programmes in River Basins), 191-200.

Gurnell, A. M., A. Hodson, M.J. Clark, J. Bogen, J. O. Hagen and M. Tranter. 1994. Water and sediment discharge from glacier basins: an Arctic and Alpine comparison. International Association of Hydrological Sciences Publication 224 (Symposium at Canberra 1994 - Variability in Stream Erosion and Sediment Transport), 299-311.

Haworth, J. and P. Vincent. 1982. Power transformations and linear regression models in geography. Area, 14 2), 137-143.

Hodgkins, R. 1994. The seasonal evolution of meltwater discharge, quality and routing at a High-Arctic glacier. (Ph.D. thesis, University of Cambridge.

Hodson, A. 1994. Climate, hydrology and sediment transfer process interactions in a sub-polar glacier basin, Svalbard. (Ph.D. thesis, University of Southampton.)

Humphrey, N., C. Raymond and W. Harrison. 1986. Discharges of turbid water during mini-surges of Variegated Glacier, Alaska, U.S.A. J. Glaciol., 32(111), 195-207.

Liestol, O. 1967. Storbreen glacier in Jotunheimen, Norway, Nor. Polarinst. Skr. 141.

Repp, K. 1988. The hydrology of Bayelva, Spitsbergen. Nord. Hydrol., 19 (4), 259-268.

Water Research Association. 1970. River flow measurement by dilution gauging. Medmenham, Water Research Association. Technical Paper TP-74.)) 